\title{
Permeability and seismic velocity anisotropy across a ductile-brittle fault zone in crystalline rock
}

\author{
Quinn C. Wenning ${ }^{1}$, Claudio Madonna ${ }^{1}$, Antoine de Haller ${ }^{2}$, and Jean-Pierre Burg ${ }^{1}$ \\ ${ }^{1}$ Department of Earth Sciences, Institute of Geology, ETH Zurich, Zurich, Switzerland \\ ${ }^{2}$ Department of Earth Sciences, University of Geneva, Geneva, Switzerland
}

Correspondence: Quinn C. Wenning (quinn.wenning@erdw.ethz.ch)

Received: 2 March 2018 - Discussion started: 5 March 2018

Revised: 30 April 2018 - Accepted: 8 May 2018 - Published: 29 May 2018

\begin{abstract}
This study characterizes the elastic and fluid flow properties systematically across a ductile-brittle fault zone in crystalline rock at the Grimsel Test Site underground research laboratory. Anisotropic seismic velocities and permeability measured every $0.1 \mathrm{~m}$ in the $0.7 \mathrm{~m}$ across the transition zone from the host Grimsel granodiorite to the mylonitic core show that foliation-parallel P- and S-wave velocities systematically increase from the host rock towards the mylonitic core, while permeability is reduced nearest to the mylonitic core. The results suggest that although brittle deformation has persisted in the recent evolution, antecedent ductile fabric continues to control the matrix elastic and fluid flow properties outside the mylonitic core. The juxtaposition of the ductile strain zone next to the brittle zone, which is bounded inside the two mylonitic cores, causes a significant elastic, mechanical, and fluid flow heterogeneity, which has important implications for crustal deformation and fluid flow and for the exploitation and use of geothermal energy and geologic waste storage. The results illustrate how physical characteristics of faults in crystalline rocks change in fault zones during the ductile to brittle transitions.
\end{abstract}

\section{Introduction}

Brittle faults and ductile shear zones and their associated damage and high-strain zones have a localized yet influential impact on crustal mechanics and fluid flow (see reviews by Sibson, 1994; Faulkner et al., 2010). Physical properties in and around the fault core and damage zone in the brittle regime generally differ from the host rock by several or- ders of magnitude, asserting tremendous influence on fluid flow, deformation, earthquake rupture, and the development of economically exploitable resources. Less is known about the nature of the physical properties of ductile shear zones, and their role in crustal mechanics and fluid flow distribution once they are exhumed (e.g., Bolognesi and Bistacchi, 2016; Donath, 1961). Thus, understanding the nature of the geometrical distribution and temporal evolution of the properties associated with ductile shear zones and their transition into brittle faults and damage zones is integral to assess crustal mechanics and fluid flow distribution.

The characterization of brittle faults and damage zones has received much attention (see review by Faulkner et al., 2010). Previous studies from the laboratory $(\mathrm{cm})$ to field outcrop $(\mathrm{km})$ scale have developed into generalized models for the mechanical and hydraulic behavior of fault zones (e.g., Chester and Logan, 1986; Caine et al., 1996; Faulkner et al., 2003, 2010). These models suggest that the fault zone consists of single or multiple high-strain cores surrounded by a damage zone where the physical properties are a function of the rock matrix, fracture density, and fault core. Brittle faults generally increase in fracture density in the damage zone towards the fault core (Vermilye and Scholz, 1998; Wilson et al., 2003; Mitchell and Faulkner, 2009), thereby increasing permeability and reducing elastic and mechanical strength from the intact rock towards the central fault core. Mitchell and Faulkner (2012) show that the microfracture density that enhances permeability around brittle faults scales with the displacement of the fault. Laboratory experiments on Westerly granite indicate that increasing permeabil- 
ity due to microfracturing occurs regardless of the tectonic faulting regime (Faulkner and Armitage, 2013).

In the ductile deformation regime, shear zones are understood to develop anisotropic properties due to mineral alignment of anisotropic minerals in preferred elongation directions (shape-preferred orientation or SPO) and/or alignment of the crystallographic axis (crystallographic preferred orientation or CPO) of minerals (Mainprice, 2007). The characteristics of ductile shear zones have been studied in terms of their anisotropic velocity structure to assess observations in middle to lower crustal seismic reflectivity (see review by Almqvist and Mainprice, 2017). Rey et al. (1994) suggested that the physical properties in ductile shear zones should also be considered as transitional (i.e., the seismic velocities would grade into the ductile shear zone core). The strength of ductile shear zones is typically studied in terms of viscous rheology (e.g., Sibson, 1983). However, these shear zones are often "frozen in" and preserve their textural features that when exhumed behave with elastic and frictional failure criteria in the upper crust. In preserved ductile shear zones, mechanical and fluid flow properties have typically been studied separately. Géraud et al. (1995) studied the porosity and mineral structure across a mylonitic shear zone. Using empirical relationships between porosity and pore throat diameter, these authors were able to discern that the permeability decreases in the highest strained sample. Violay et al. (2017) performed triaxial deformation experiments across the brittle-ductile transition in Westerly granite and show that porosity changes in the ductile regime is compactant, while the brittle regime is marked by dilation.

The models for elasticity and permeability through brittle and ductile shear zones have been mostly derived from outcrop examples (Faulkner et al., 2010, and references therein). To date, there have been limited systematic mechanical and fluid flow studies on boreholes that directly penetrate fossil ductile shear zones. Drilling into fractured crystalline rock for geothermal exploitation has been ongoing since the 1970s (Vidal and Genter, 2018). Recent drilling through the Alpine Fault in New Zealand revealed how ductile mylonites have been exhumed, altering the rocks to a typical brittle fault damage zone in the vicinity to the fault (Allen et al., 2017). Although much precaution is taken in outcrop studies, core material provides the opportunity to sample systematically into a fault zone eliminating issues of surface weathering and processes that may alter physical properties. However, precaution should be taken when assessing the extent and timing of hydrothermal alteration associated with faults at depth. Additionally, focus on the relationship between elasticity, mechanical strength, and permeability in the transition zone and core of faults has been inherently focused on brittle structures. However, with the importance of meeting sustainable energy demands via geothermal energy and promoting safe geological waste disposal, the impact of preserved ductile structures in granitic rocks on mechanics and fluid flow are also if increasing significance.(Violay et al., 2017; Watanabe et al., 2017).

Recent drilling at the Grimsel Test Site (GTS), an underground research laboratory owned and operated by NAGRA (National Cooperative for the Disposal of Radioactive Waste) located in central Switzerland, penetrated a $\sim 5 \mathrm{~m}$ thick ductile-brittle fault damage zone relict in the Grimsel granodiorite host rock (Amann et al., 2018). Alpine tectonism produced multiple stages of ductile and subsequently brittle deformation in the Grimsel granodiorite, a member of the Aar massif (e.g., Rolland et al., 2009; Belgrano et al., 2016; Wehrens et al., 2016, 2017). The relict shear zone penetrated by the borehole is bounded by two foliated ductile shear zones, which initially localized ductile deformation and further reactivated brittlely between the two foliated shear zones. This study concentrates on characterizing the elastic and fluid flow properties from the surrounding granodiorite rock mass through the ductile transition zone into the bounding foliated shear zone. Seismic P- and S-wave velocities $\left(V_{\mathrm{p}}\right.$ and $\left.V_{\mathrm{s}}\right)$ and gas permeability $(k)$ were measured on core samples in the laboratory. This paper emphasizes that the mineralogical changes entering the shear zone influence changes in physical properties near the ductile-brittle damage zone. The results also provide insight on the transient behavior of faults during the transition from ductile to brittle regimes through exhumation processes and provide insight on their effect on economic exploitation of such shear zones in terms of geothermal energy or geological waste disposal.

\section{Geologic setting and core details}

The GTS is located in the Aar Massif in central Switzerland (Fig. 1a). The underground laboratory is situated in Grimsel granodiorite in the Haslital. Schaltegger and Corfu (1992) place the age of the Grimsel granodiorite at $299 \pm 2 \mathrm{Ma}$. From field relations and dating, the Grimsel granodiorite has the same age as the Central Aar granite. These intrusions postdate Variscan collision, and there are no identified preAlpine deformation structures.

Detailed deformation histories of the Grimsel region are available (Challandes et al., 2008; Rolland et al., 2009; Belgrano et al., 2016; Wehrens et al., 2016, 2017), which are summarized here. From argon-argon and rubidiumstrontium dating, as well as field relations, beginning around $21 \mathrm{Ma}$ and continuing until approximately $10 \mathrm{Ma}$, ductile deformation resulting from transpression created NNE-SSW, E-W, and NW-SE striking shear zones with steep dips to the south (Fig. 1a). Ductile deformation is believed to occur in two stages: (1) NNW-vergent thrusting from 21 to $17 \mathrm{Ma}$ and (2) transpression causing dextral shearing of preferentially oriented oversteepened stage 1 structures from 14 to $10 \mathrm{Ma}$. Beginning around $9 \mathrm{Ma}$ steady exhumation caused retrograde ductile-brittle deformation in the form of discrete fractures, 

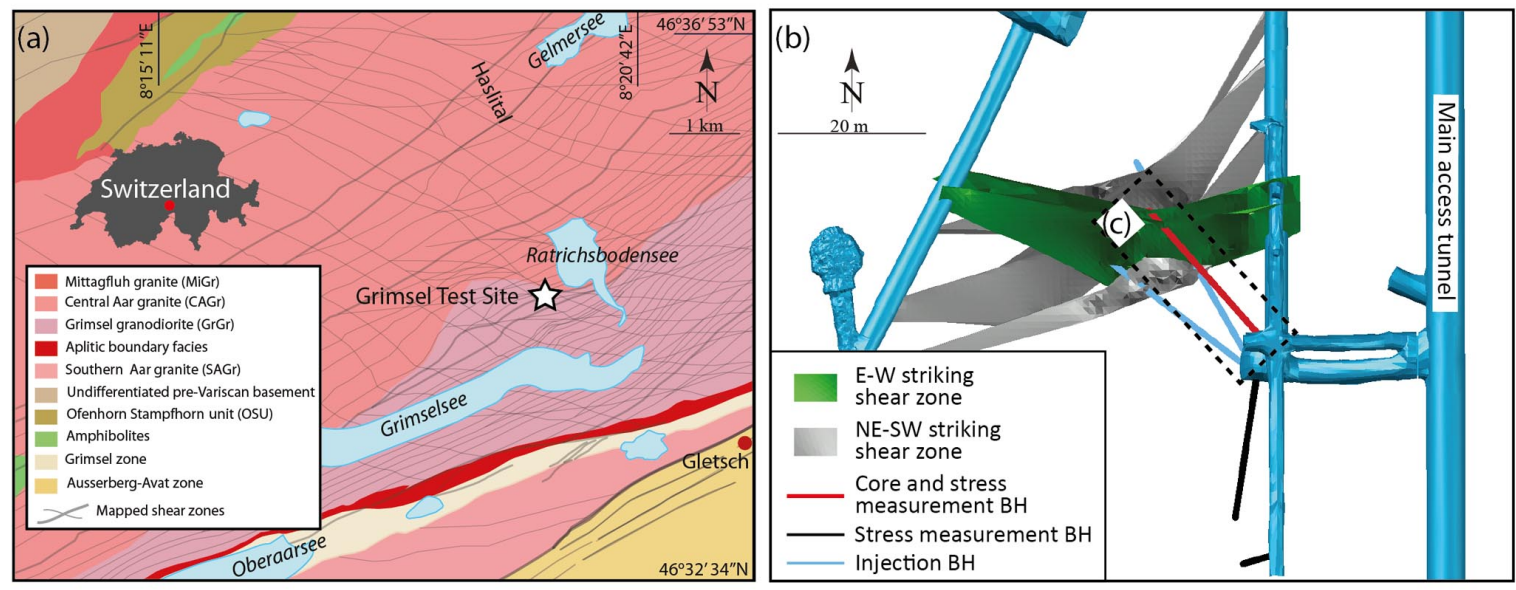

(c)

Drill azimuth:

$\sim 319^{\circ}$

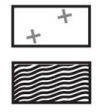

Granodiorite

-.. Core measurement locations

Mylonite

Depth (start):

1733 m.a.s.l.

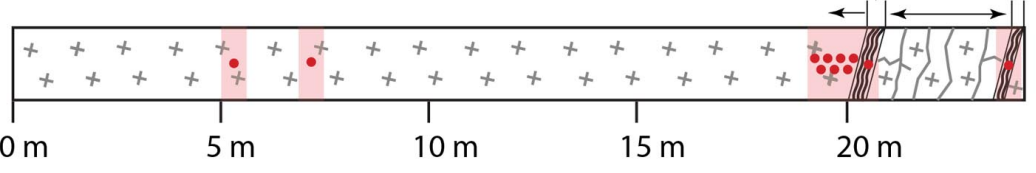

Depth (base):

1735 m.a.s.l.

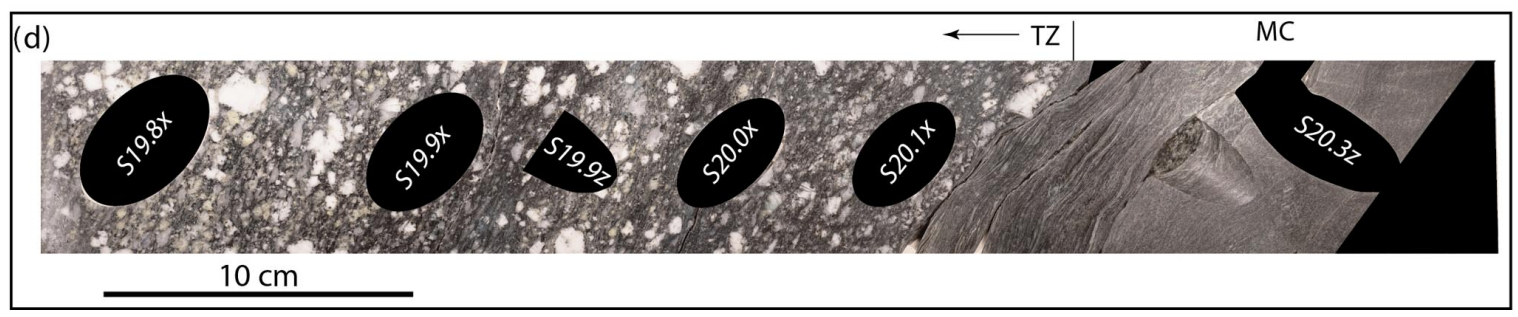

Figure 1. (a) Geologic map of the Grimsel pass region (after Wehrens et al., 2016, 2017); (b) borehole orientations (this study - red borehole) with respect to the underground research laboratory (after Krietsch et al., 2017; Amann et al., 2018); (c) the borehole in this study depicting the location of the damage zone with coring and stress measurement locations projected along the borehole. The shear zone at the base is divided into three components: (1) transition zone (TZ), (2) mylonitic core (MC), and (3) damage zone (DZ). (d) Photograph of a saw-cut cross section through part of the transition zone and the mylonitic core (black ellipses show subcored cylinders inclined to the cut surface).

and subsequent embrittlement of these shear zones, which has produced fault breccias, cataclasites, and fault gouge.

The Aar granites experienced $300-450{ }^{\circ} \mathrm{C}$ and 150 to $250 \mathrm{MPa}$ peak conditions during Alpine metamorphism (Steck, 1968; Rolland et al., 2009; Wehrens et al., 2016, 2017). Our thin section observation shows fracturing of feldspar and undulose extinction along with subgrain boundaries in quartz, which are consistent with the inferred metamorphic temperatures.

In 2015, a series of boreholes were drilled in the Grimsel granodiorite (Fig. 1b) for stress measurements, petrophysical property characterization, and hydraulic stimulation of the shear zones (Amann et al., 2018). The core material used in this study comes from the borehole drilled from an offset of the main tunnel in the GTS that penetrates two parallel shear zones. The well was drilled from $480 \mathrm{~m}$ below the ground surface in a subhorizontal trajectory with an azimuth of $319^{\circ}$. The well penetrates $\sim 20 \mathrm{~m}$ of mostly non-fractured granodiorite (Fig. 1c). The granodiorite is foliated and at $20.2 \mathrm{~m}$ intersects a $20 \mathrm{~cm}$ thick foliated mylonitic shear zone, also defined as a foliated mylonitic core (MC). The foliation intensity in the granodiorite decreases towards the host rock $\sim 0.5 \mathrm{~m}$ from the MC through the transition zone (TZ) and is concordant with the foliation in the steeply dipping E-Woriented MC (Krietsch et al., 2017). The TZ has a gradual decrease in grain size of both matrix grains and the felsic clasts with more frequent mylonitic shear bands towards the MC (Figs. 1d and 2). The MC itself is heterogeneously banded with mylonite and ultramylonite layers. A brittle damage zone (DZ) mixed with small $<5 \mathrm{~cm}$ thick mylonitic shear zones is bounded between the MC at $20.2 \mathrm{~m}$ and another $20 \mathrm{~cm}$ thick MC at the end of the borehole (Fig. 2). Less than 
(a)
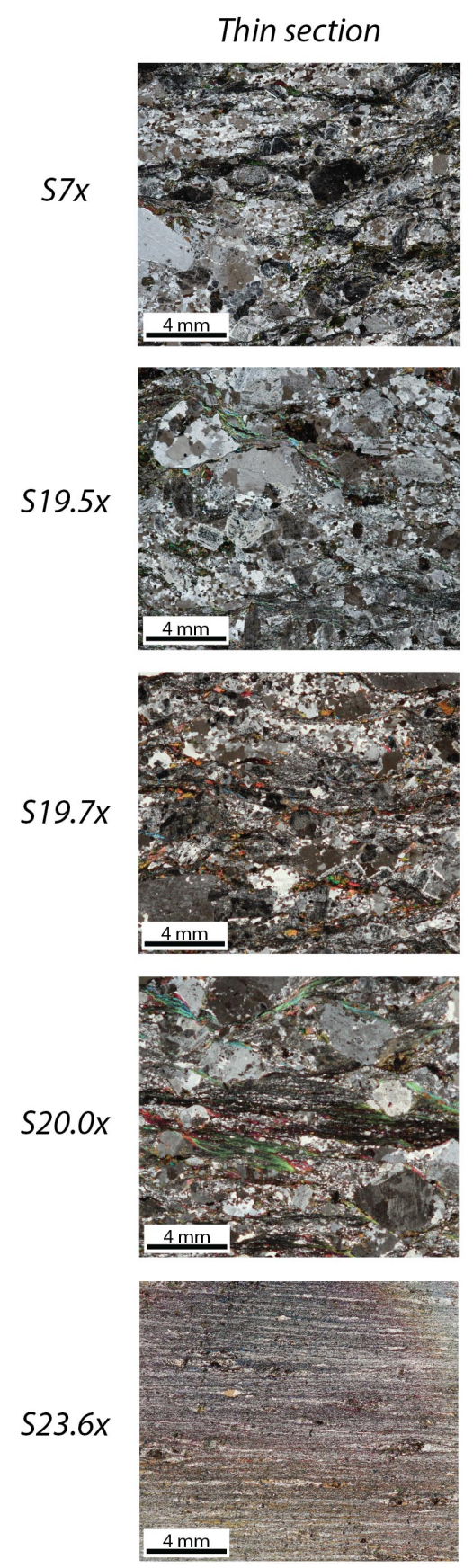

(b)

QEMSCAN
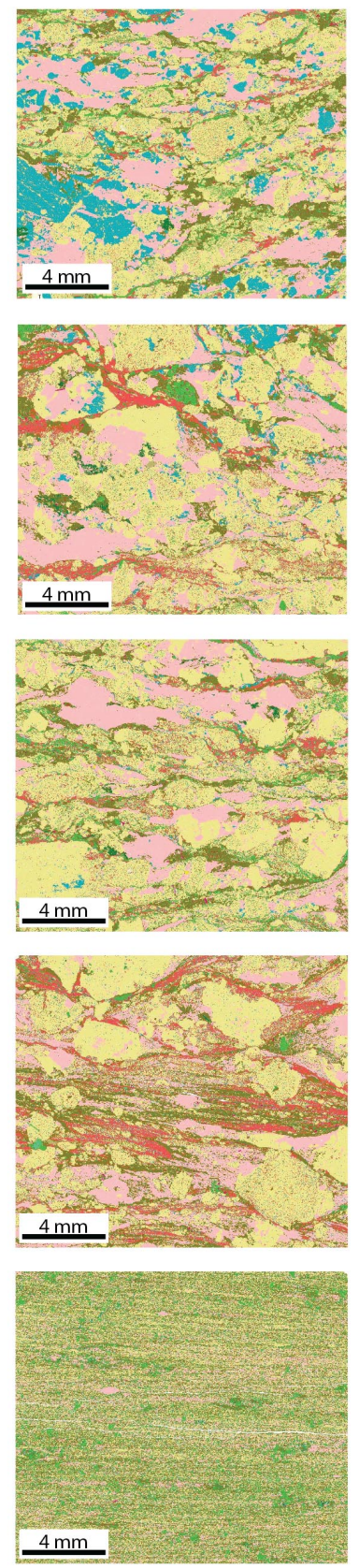

QEMSCAN legend

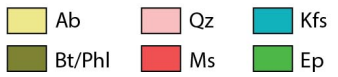

(c)

Microstructure
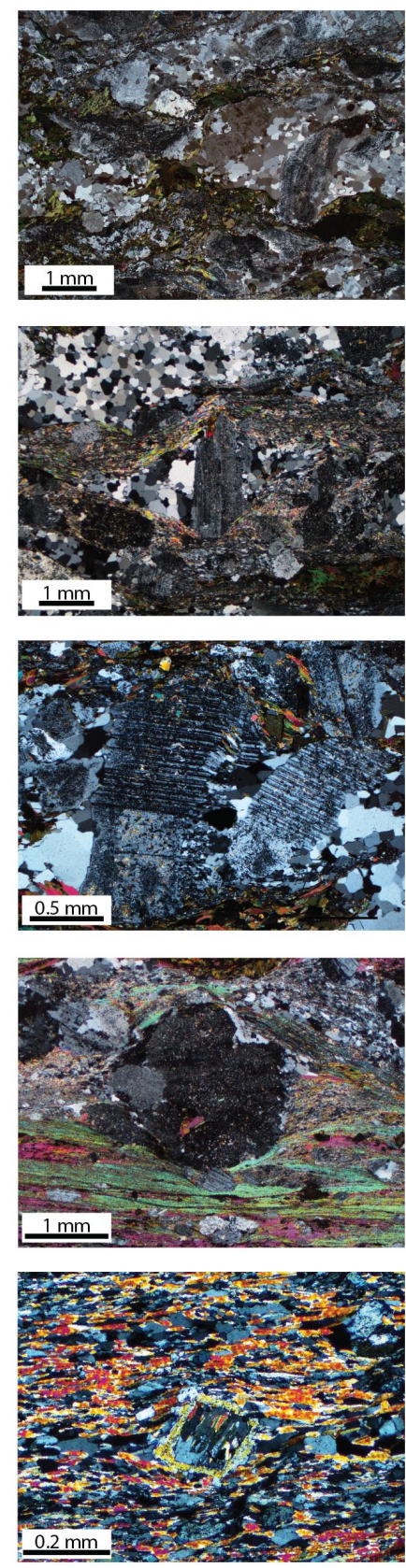

Figure 2. Optical microscopy and QEMSCAN ${ }^{\circledR}$ images of thin sections for each $x_{1}$ sample (S7x, S19.5x, S19.7x, S20.0x, and S23.6x). Panel (a) shows the cross-polarized light image of the sample with the corresponding QEMSCAN ${ }^{\circledR}$ area in (b). Panel (c) depicts a particular microstructure of the sample. S7x - typical host rock texture with twinned feldspar and quartz. S19.5x - elongated feldspar with quartz in strain shadows between fine-grained mica. S19.7x - fractured feldspar with quartz grains filling the fracture. S20.0x - rounded sericitic feldspar clast with fine-grained quartz and mica infilling the strain shadows between lenses of large mica grains and fine recrystallized quartz/mica. S23.6x - very fine-grained foliated biotite and quartz grains surrounding euhedral plagioclase. Sample locations depicted in Fig. 1. 
$1 \mathrm{~mm}$ aperture quartz-filled fractures intersect the MCs originating from within the damage zone. However, these do not appear to penetrate entirely through the MCs.

\section{Methods}

\subsection{Sample selection, preparation, and characterization}

In order to determine the spatial relationship of the physical properties in the shear zone a continuous set of samples was cored every $0.1 \mathrm{~m}$ in the transition zone from $19.6 \mathrm{~m}$ to the border of the first MC at $20.1 \mathrm{~m}$. Abundant fractures in the damage zone between the two MCs prevented continuous coring. Two mutually perpendicular core samples, one parallel $\left(x_{1}\right)$ and one perpendicular $\left(x_{3}\right)$ to the Grimsel granodiorite foliation were taken to characterize the physical property and anisotropy changes as a gradient away from the mylonitic core. Sampling farther than $19.5 \mathrm{~m}$ was not possible due to previously made overcoring stress measurements (Fig. 1c). In order to optimize the number of samples, the $x_{1}$ direction was taken $\sim 15^{\circ}$ off axis from the lineation (Fig. 1d). Foliation perpendicular samples could not be taken at 19.5 and $20.1 \mathrm{~m}$ because of breaks in the core. The $x_{1}$ and $x_{3}$ samples were bored out of the core using a diamond drill bit $(2.54 \mathrm{~cm}$ inner diameter) with water as the cooling fluid. The 2.49 to $5.56 \mathrm{~cm}$ long samples were ground and polished to craft parallel ends. To characterize the MC, parallel and perpendicular to foliation samples were taken at 20.2 and $23.6 \mathrm{~m}$, respectively. There is a maximum length $(\sim 2.49 \mathrm{~cm})$ to diameter $(\sim 2.53 \mathrm{~cm})$ ratio of approximately $1: 1$ in the MC samples, due to the extremely fissile nature of these rocks. Additionally, these two samples come from separate but similar MC at the base of the borehole due to limited sample material. Since the seismic velocity measurements require longer samples due to signal noise and wave propagation issues, the MC samples are only long enough to perform only permeability measurements. Additionally, two sets of perpendicular samples were taken 5 and $7 \mathrm{~m}$ from the start of the borehole as a background Grimsel granodiorite reference.

Thin sections were prepared directly from the ends of the samples and observed under optical microscopy. Quantitative mineral analysis was obtained at the University of Geneva using QEMSCAN ${ }^{\circledR}$ Quanta 650F, an automated scanning electron microscope with mineral identification based on a combination of back-scattered electron values, energy-dispersive $\mathrm{X}$-ray spectra, and X-ray count rates. High-resolution mineralogical and petrographic maps were obtained with the QEMSCAN $^{\circledR}$ at a scanning resolution of $5 \mu \mathrm{m}$, which measures the mineral coverage in percent area.

\subsection{Density, porosity, and permeability measurements}

Measurements of matrix volume and mass were performed after the samples were dried in an oven at $100^{\circ} \mathrm{C}$ for $24 \mathrm{~h}$ for the granodiorite samples and $40^{\circ} \mathrm{C}$ for the fragile $\mathrm{MC}$ samples. The matrix volume was measured using a helium pycnometer (AccuPyc 1330, Micromeritics ${ }^{\circledR}$ ). The dry mass was measured with a precision balance. The bulk rock density $\rho_{\text {bulk }}$ was calculated as the dry mass divided by the matrix volume of the sample. The porosity $(\phi)$ of each cylindrical sample was calculated from the geometrical volume ( $\left.V_{\text {tot }}\right)$ and the matrix volume $\left(V_{\mathrm{m}}\right)$ from the helium pycnometer $\phi=\left(V_{\text {tot }}-V_{\mathrm{m}}\right) / V_{\text {tot }}$.

A hydrostatic pressure vessel was used to measure the gas permeability of each sample (detailed description of the apparatus and measurement technique in Pini et al., 2009). The hydrostatic pressure vessel is equipped to measure samples of $2.5 \mathrm{~cm}$ in diameter and up to $\sim 5 \mathrm{~cm}$ in length at confining pressures up to $20 \mathrm{MPa}$. Hydraulic oil is used as the confining fluid, which is controlled with a screwtype displacement pump that regulates the confining pressure within $\pm 0.05 \mathrm{MPa}$. The sample assembly consists of the cylindrical rock specimen placed between two stainless steel disks fastened by a soft PVC tube to isolate the sample from the confining fluid. The two stainless steel disks have interconnected circular grooves to distribute the fluid across the cross-sectional area of the sample. The disks are connected via a plumbing system to the upstream and downstream reservoirs, which can be isolated and filled with the injected gas. The upstream and downstream reservoir, plus their associated plumbing network, have volumes of $50.8 \mathrm{~cm}^{3}$ and $21.2 \mathrm{~cm}^{3}$, respectively. The gas pressure in the two reservoirs is measured within $0.05 \%$.

Due to the low porosity and permeability in the granodioirite and MC, the transient step technique was used to perform and analyze the flow experiments (Brace et al., 1968). Experiments were performed at room temperature and an effective pressure of $10 \mathrm{MPa}$, chosen to represent the effective stress conditions in the GTS. Three confining pressure and pore pressure configurations that preserved an effective pressure of $10 \mathrm{MPa}$ were performed to assess the Klinkenberg gas slippage effect (Klinkenberg, 1941). For each sample a pressure difference of $0.5 \mathrm{MPa}$ was imposed between the upstream $\left(P_{\mathrm{us}}\right)$ and downstream $\left(P_{\mathrm{ds}}\right)$ reservoir and allowed to equilibrate at each of the pore pressure configurations (e.g., $P_{\mathrm{us}}$ and $P_{\mathrm{ds}}=1.0$ and $0.5 \mathrm{MPa}, 3.0$ and $2.5 \mathrm{MPa}$, and 7.0 and $6.5 \mathrm{MPa}$, respectively). In some cases, the sample permeability was so low that reaching a full equilibrium between the up- and downstream reservoir was not possible within laboratory timescale. For these samples, only the beginning part of the partial pressure gradient equilibration has been assessed (correlating to a pressure drop of $<0.1 \mathrm{MPa}$ ).

Hsieh et al. (1981) developed a full analytical solution to the differential equation describing the gas pressure inside the sample as a function of the distance along the sample 
and time to estimate permeability. Dicker and Smits (1988) developed a simple analytical expression to estimate permeability from the measured pressure curves. The simple analytical solution

$k=\frac{\beta \mu \phi L^{2} s}{f\left(V_{\mathrm{sa}} / V_{\mathrm{us}}, V_{\mathrm{sa}} / V_{\mathrm{ds}}\right)}$

is a function of the compressibility, $\beta$, and viscosity, $\mu$, porosity, $\phi$, length of the sample, $L$, slope of the differential pressure vs. time, $s$, and a function of the ratio between the volume of the sample $\left(V_{\mathrm{sa}}\right)$ and the volume of the upand downstream reservoirs ( $V_{\mathrm{us}}$ and $V_{\mathrm{ds}}$, respectively). The solution is accurate within $0.3 \%$ of the full expression if the pore volume is less than the reservoir volumes, which is true for our experiments. Since the pressure difference in the two reservoirs is small, we used an average pore pressure to determine the compressibility and viscosity of the argon gas using the NIST database (NIST, 2017).

\subsection{Elastic wave velocity measurements and calculations}

A separate hydrostatic oil-medium pressure vessel, capable of reaching high confining pressures, was used to measure the $\mathrm{P}$ - and S-ultrasonic elastic wave velocities using the pulse transmission technique (Birch, 1960). The measurements were conducted on the mutually perpendicular samples up to $260 \mathrm{MPa}$ and at room temperature conditions (detailed description of the measurements found in Zappone et al., 2000). The mechanical impulse is directed into the sample by mounting the lead zirconate titanate piezoceramic transducer inside a "head" assembly that also contains a buffer rod, reducing the dispersion of energy. The setup is configured so that one transducer transforms the electrical impulse (1 MHz resonance frequency) and emits a mechanical wave at the coupling of the transducer with the sample. After passing through the sample, another transducer converts the mechanical wave back into an electrical signal. The electronic system consists of a Hewlett Packard ${ }^{\circledR}$ 214B Pulse Generator that is connected to the transducers with coaxial cables and the output is recorded directly with a computer. To prevent oil seepage from the confining fluid into the sample, a thin polyolefin heat shrink tube is fitted over the ends of the transducers and the sample.

The velocity in the rock is given by

$V_{\mathrm{p}, \mathrm{s}}=\frac{L}{t_{\mathrm{sample}}}$ with $t_{\mathrm{sample}}=t_{\mathrm{total}}-t_{\mathrm{system}}$

where the $\mathrm{P}$ - and $\mathrm{S}$-wave velocities, $V_{\mathrm{p}, \mathrm{s}}$, are a function of the travel time through the sample, $t_{\text {sample }}$, and its length, $L$. The travel time through the sample is determined by subtracting the travel time of the cabling in the source-receiver system, $t_{\text {system }}$, from the total time of flight of the impulses recorded, $t_{\text {total }}$.
The waveforms are recorded at stepwise increases or decreases in pressure in the loading and unloading cycles performed for each $\mathrm{P}$ - and S-wave experiment. Measurements were recorded across the full pressure range of 30 to $260 \mathrm{MPa}$ of the apparatus to investigate the properties closest to present-day low-pressure conditions at the GTS (minimum principal stress 8 to $12 \mathrm{MPa}$, maximum principal stress 13$17 \mathrm{MPa}$ Krietsch et al., 2017) and to study the poro-elastic effect on seismic velocities after crack closure at high pressure (Birch, 1960). The measurements were made at room temperature and in dry, undrained conditions. Recordings of the waveform were measured within $\pm 2 \mathrm{MPa}$ and a travel time accuracy of $\pm 0.01 \mu \mathrm{s}$.

Velocity anisotropy $(\mathrm{A} V)$ was estimated from the maximum, minimum, and mean velocities using

$\mathrm{A} V_{\mathrm{p}, \mathrm{s}}=\frac{V_{\mathrm{p}, \mathrm{s} \text { max }}-V_{\mathrm{p}, \mathrm{s} \text { min }}}{V_{\mathrm{p}, \mathrm{s} \text { mean }}} \cdot 100$.

Estimates of the dynamic elastic moduli were also calculated for each experiment. The P- and S-wave moduli are represented in the general form as $c_{x x}=\rho V_{\mathrm{p}, \mathrm{s}}^{2}$. The P-wave moduli for the vertical $\left(x_{3}\right)$ and maximum horizontal $\left(x_{1}\right)$ samples are represented by $c_{33}$ and $c_{11}$, respectively. Similarly, the S-wave moduli, also known as shear modulus $(\mu)$, for the vertical and maximum horizontal samples are represented by $c_{44}$ and $c_{66}$, respectively. The elastic moduli are estimated by applying the isotropic equations to the vertical and horizontal components separately in order to estimate the $\mathrm{P}$ - and $\mathrm{S}$-wave moduli (Mavko et al., 2009). Sone and Zoback (2013) show that the error in applying the isotropic equations to the vertical and horizontal components separately in the absence of having the $45^{\circ}$-oriented sample is negligible. The dynamic Young's moduli are approximated for the parallel $\left(E_{1}\right)$ and perpendicular $\left(E_{3}\right)$ components using the following equations:

$E_{1}=\frac{c_{66}\left(3 c_{11}-4 c_{66}\right)}{c_{11}-c_{66}}$,
$E_{3}=\frac{c_{44}\left(3 c_{33}-4 c_{44}\right)}{c_{33}-c_{44}}$.

The dynamic Poisson's ratio for the parallel $\left(v_{1}\right)$ and perpendicular $\left(v_{3}\right)$ sample is calculated using the isotropic equation

$v=\frac{1}{2} \frac{\left(V_{\mathrm{p}} / V_{\mathrm{s}}\right)^{2}-2}{\left[\left(V_{\mathrm{p}} / V_{\mathrm{s}}\right)^{2}-1\right]}$.

The dynamic bulk modulus for the parallel $\left(K_{1}\right)$ and perpendicular $\left(K_{3}\right)$ sample is calculated using the isotropic equation

$K=\rho\left(V_{\mathrm{p}}^{2}-\frac{4}{3} V_{\mathrm{s}}^{2}\right)$. 


\section{Results}

\subsection{Characterization}

In general there is a decrease in grain size in the TZ toward the MC (Fig. 1d; data available in Wenning et al., 2018). Additionally, millimeter-thick shear bands become more frequent nearer to the MC until reaching the sharp boundary with the MC. The MC itself is heterogeneously layered and folded. The compositional and microstructural transition from the "host" granodiorite, through the transition zone (TZ), and the mylonitic core (MC) are depicted in Fig. 2 and the rock composition is summarized in Table 1. The density of granodiorite samples irrespective of their proximity to the MC varies between 2.72 and $2.78 \mathrm{~g} \mathrm{~cm}^{-3}$ with porosity varying between 0.4 to $1 \%$ (Table 1 ). In general, the samples do not have visible open microcracks; thus, the porosity occurs between grain contacts (i.e., intergranular micropores). The density of the MC from both sampling locations is 2.80 and $2.84 \mathrm{~g} \mathrm{~cm}^{-3}$ and porosity estimates are 0 and $1 \%$, respectively.

The samples (S5 to S20.1) from the granodiorite are made up of various amounts of plagioclase (albite), quartz, $\mathrm{K}$-feldspar, biotite/phlogopite, muscovite, and epidote. The amount of each mineral phase and microstructure depends on the vicinity to the mylonitic core. In the samples taken from the host granodiorite (S5 and S7) as well as samples farthest from the mylonitic core (S19.5 and S19.6) the microstructure and composition is similar. Plagioclase is the most abundant mineral phase $(\sim 40 \%)$. The sub-millimeter to $>10 \mathrm{~mm}$ big plagioclase grains are rounded to subangular. The grain size of plagioclase varies from sub-millimeter to $>10 \mathrm{~mm}$. Needle-like sericite inclusions $(<0.1 \mathrm{~mm})$ form within the plagioclase cleavage planes, indicating that hydrothermal alteration occurred. Quartz subgrains also develop along the boundaries and within large plagioclase grains. In larger plagioclase grains brittle fractures are filled with biotite and quartz. Quartz is the second-most abundant mineral phase ( $\sim 17$ to $25 \%)$. Quartz grains of variable size $(<1-2 \mathrm{~mm})$ typically occur as many rounded to subhedral individual subgrains that form lenses or develop in the strain shadows of plagioclase clasts (Fig. 2). The main difference between the host granodiorite (S5 and S7) and the beginning of the transition zone (S19.5 and S19.6) is the K-feldspar concentration, which is $\sim 15$ to $17 \%$ and $\sim 5 \%$, respectively. Phyllosilicates in the form of biotite and muscovite form anastamosing lenses of mixed muscovite and biotite with variable thickness across the thin section, which comprise about 15 to $18 \%$ of the total mineralogy. Biotite forms $<0.1$ to $1 \mathrm{~mm}$ grains, of which the individual grains are randomly oriented in the anastamosing lenses.

A progressive change in the overall microstructure, state of the individual minerals, and the mineral composition is observed in the transition zone between samples S19.7 and S20.1. In Sample S19.7 the foliation becomes more contin- uous across the thin section when compared to the host granodiorite samples. Plagioclase deforms brittlely in the form of fracturing (Fig. 2), while grain boundary migration, undulose extinction, and subgrain rotation is observed in the quartz grains indicates ductility. Plagioclase and quartz grain size are similar to host granodiorite. Lenses of biotite and muscovite extend across the thin section more continuously; however, the lenses form variable thicknesses that wrap around the intermixed plagioclase and quartz. The anastomosing lenses are still present. In the samples nearest the MC (S20.0 and S20.1), the continuity and thickness of the micarich layers across the sample are the most developed. The foliation planes are oriented towards the parallel alignment of the individual grains. Biotite and muscovite grains are especially larger in samples S20.0 and S20.1, where individual grains can be $>5 \mathrm{~mm}$ long. While lenses of fine-grained phyllosilicates occur, the overall grain size, continuity, layer thickness, and orientation of the individual grains is greater and more continuous. The total phyllosilicate amount increases from $\sim 15$ to $18 \%$ in samples S5 to S19.6 to 30\% in samples S20.0 and S20.1, with the other tectosilicates (plagioclase, $\mathrm{K}$-feldspar, and quartz) reducing as a result. Biotite and quartz appear in the strain shadows of the plagioclase clasts (Fig. 2).

The MC sample (S23.6) is constituted of very fine-grained ultramylonitic (more than $90 \%$ grain size reduction) plagioclase $(31 \%)$, biotite $(27 \%)$, quartz $(22 \%)$, and epidote $(12 \%)$ making up the main mineral constituents. The foliation is defined by the biotite-quartz/plagioclase preferred shape orientation (layers typically $<0.1 \mathrm{~mm}$ ). Recrystallized plagioclase and quartz form rotated clasts within the biotitequartz foliation. The shear zones in the region are often interpreted as former mafic dykes (e.g., Wehrens et al., 2017). The MC has a gradient of deformation between the Grimsel granodiorite in the TZ and the MC, and most notably there is a heterogeneous layering within the ultramylonite with larger grain lenses that are compositionally similar to the granodiorite (e.g., Fig. 1d). We interpret this structure more broadly as a mylonitic shear zone with a strain gradient of decreasing deformation away from the mylonitic cores.

\subsection{Velocity measurements and elastic moduli calculation}

Seismic velocities (Fig. 3 and Table 2; data available in Wenning et al., 2018) are reported for the $30 \mathrm{MPa}$ confining pressure measurement (i.e., the closest measurement to the stress magnitudes in the GTS). The measured velocities parallel to foliation at $30 \mathrm{MPa}$, (Fig. 3 and Table 2) show an increase across the $\sim 0.5 \mathrm{~m}$ transition zone. In the two samples taken from the host granodiorite (S5 and S7) P-wave velocity parallel to the foliation $\left(V_{\mathrm{p} x_{1}}\right)$ are $\sim 5.5 \mathrm{~km} \mathrm{~s}^{-1}$. Samples $\mathrm{S} 19.5$ to S19.7 taken from the beginning of the transition zone have comparable velocities to the host granodiorite samples (5.55 to $5.61 \mathrm{~km} \mathrm{~s}^{-1}$ ). Transitioning towards the mylonitic 

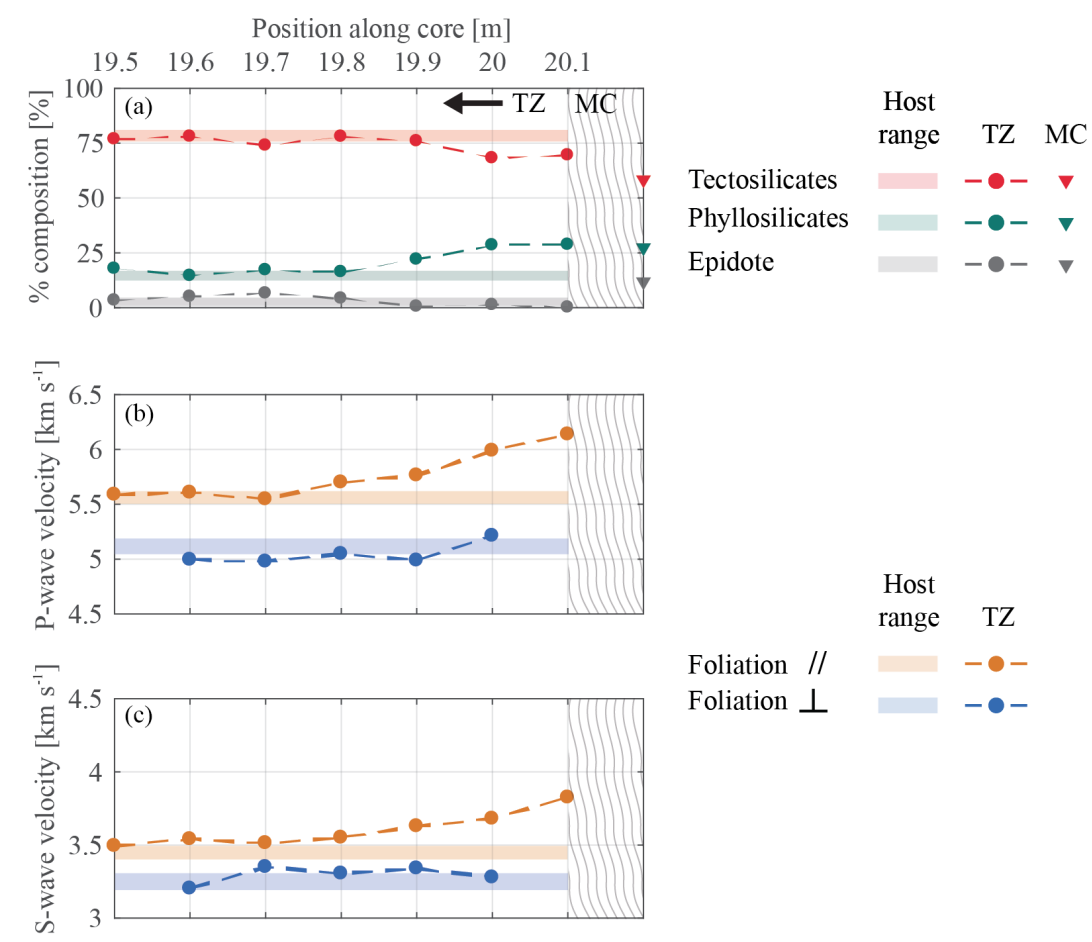

Foliation $\perp$
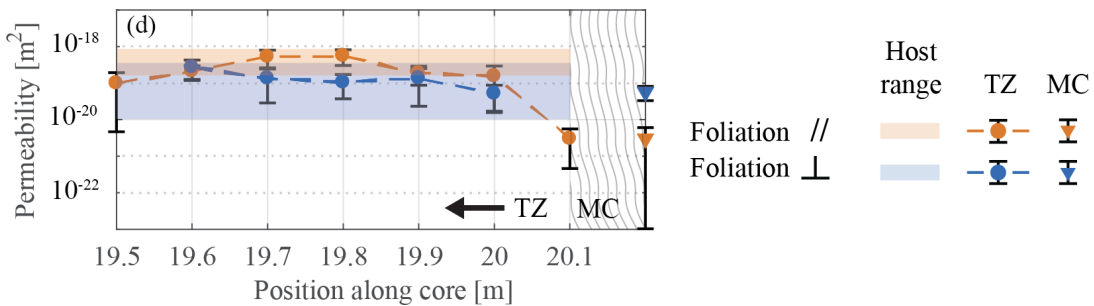

Figure 3. Sample composition, seismic velocity, and permeability across the transition zone into the mylonitic core. Depth corresponds to sample name in Table 2. (a) Tectosilicates - quartz, plagioclase, and K-feldspar (red); phyllosilicates - biotite and muscovite (green); and epidote (grey). (b, c) P- and S-wave velocity parallel to foliation (orange) and perpendicular to foliation (blue). Measured at $30 \mathrm{MPa}$ hydrostatic confining pressure. (d) Permeability parallel to foliation (orange) and perpendicular (blue). Permeability is reported as the median value measured for each sample, and the bars show the range of values in terms of minimum and maximum. Measured at $10 \mathrm{MPa}$ effective pressure. For all panels the shaded region depicts the range of values from the host granodiorite samples (S5 and S7), the circular markers show the values measured through the transition zone (TZ), and the triangular markers show the values measured in the mylonitic core (MC). Error bars are depicted where the error is larger than the marker size.

core the $V_{\mathrm{p} x_{1}}$ increases steadily and reaches a maximum in sample S20.1 $\left(6.14 \mathrm{~km} \mathrm{~s}^{-1}\right)$ directly adjacent to the MC at $20.2 \mathrm{~m}$. The S-wave velocity follows a similar trend where the host samples and the samples farthest from the mylonitic core have a $V_{\mathrm{s} x_{1}}$ of $\sim 3.42$ to $3.54 \mathrm{~km} \mathrm{~s}^{-1}$ and the velocities increase steadily and reach a maximum nearest the MC (S20.1: $V_{\mathrm{s} x_{1}}=3.83 \mathrm{~km} \mathrm{~s}^{-1}$ ). The velocities measured perpendicular to the foliation, $V_{\mathrm{p} x_{3}}$ and $V_{\mathrm{s} x_{3}}$, fluctuate without a consistent trend between 4.98 and $5.21 \mathrm{~km} \mathrm{~s}^{-1}$ and 3.20 and $3.35 \mathrm{~km} \mathrm{~s}^{-1}$, respectively. The P- and S-wave anisotropy is generally lower away from and higher near the MC. However, there are outliers (e.g., S19.6), which can be attributed to bias from either a slower $x_{3}$ velocity or a faster $x_{1}$ velocity.
The seismic velocities are in general agreement with previous measurements on Grimsel granodiorite (Keusen et al., 1989) and other granodiorite samples (Jones and Nur, 1982).

The dynamic elastic moduli behave like the velocities because the density remains consistent for each sample. Therefore, the velocities exert greater influence on the $x_{1}$ and $x_{3}$ moduli. Approaching the $\mathrm{MC}$ each respective dynamic elastic moduli increases by 10 to $20 \mathrm{GPa}$ for the $x_{1}$ sample, while the $x_{3}$ remains almost constant, which corroborates previous measurements on Grimsel granodiorite (Keusen et al., 1989). The dynamic Poisson's ratio remains relatively uniform throughout. 
Table 1. Summary of sample composition: sample name refers to depth in the borehole; rock type refers to either the host granodiorite, transition zone (TZ), or mylonitic core (MC); dry bulk density and porosity are reported as an average of individual measurements for each sample $\left(x_{1}\right.$ and $\left.x_{3}\right)$; and mineral composition is derived from the QEMSCAN analysis of the $x_{1}$-thin section in $\%$ area. Mineral abbreviations: $\mathrm{Bt}$ - biotite; Phl - phlogopite; Ms - muscovite; Ep - epidote; Ab - albite; Kfs - K-feldspar; and Qz - quartz.

\begin{tabular}{llrrrrrrrrr}
\hline Sample & $\begin{array}{l}\text { Rock } \\
\text { type }\end{array}$ & $\begin{array}{r}\text { Density } \\
\left(\mathrm{g} \mathrm{cm}^{-2}\right)\end{array}$ & $\begin{array}{r}\text { Porosity } \\
(\%)\end{array}$ & $\begin{array}{r}\text { Bt+Phl } \\
(\%)\end{array}$ & $\begin{array}{r}\text { Ms } \\
(\%)\end{array}$ & $\begin{array}{r}\text { Ep } \\
(\%)\end{array}$ & $\begin{array}{r}\text { Ab } \\
(\%)\end{array}$ & $\begin{array}{r}\text { Kfs } \\
(\%)\end{array}$ & $\begin{array}{r}\text { Qz } \\
(\%)\end{array}$ & $\begin{array}{r}\text { Other } \\
(\%)\end{array}$ \\
\hline S5 & Host & 2.73 & $<1$ & 9 & 6 & 6 & 43 & 17 & 17 & 2 \\
S7 & Host & 2.73 & $<1$ & 10 & 4 & 5 & 39 & 15 & 26 & 2 \\
S19.5 & TZ & 2.74 & $<1$ & 9 & 9 & 3 & 46 & 5 & 25 & 2 \\
S19.6 & TZ & 2.75 & $<1$ & 6 & 8 & 5 & 45 & 5 & 28 & 2 \\
S19.7 & TZ & 2.76 & $<1$ & 10 & 7 & 7 & 50 & 3 & 21 & 2 \\
S19.8 & TZ & 2.75 & $<1$ & 9 & 7 & 4 & 45 & 3 & 30 & 2 \\
S19.9 & TZ & 2.73 & $<1$ & 12 & 10 & 1 & 56 & 3 & 16 & 2 \\
S20.0 & TZ & 2.77 & $<1$ & 15 & 13 & 1 & 42 & 4 & 22 & 2 \\
S20.1 & TZ & 2.73 & $<1$ & 13 & 16 & 0 & 42 & 3 & 25 & 2 \\
S23.6 & MC & 2.82 & $<1$ & 27 & 0 & 12 & 31 & 5 & 22 & 2 \\
\hline
\end{tabular}
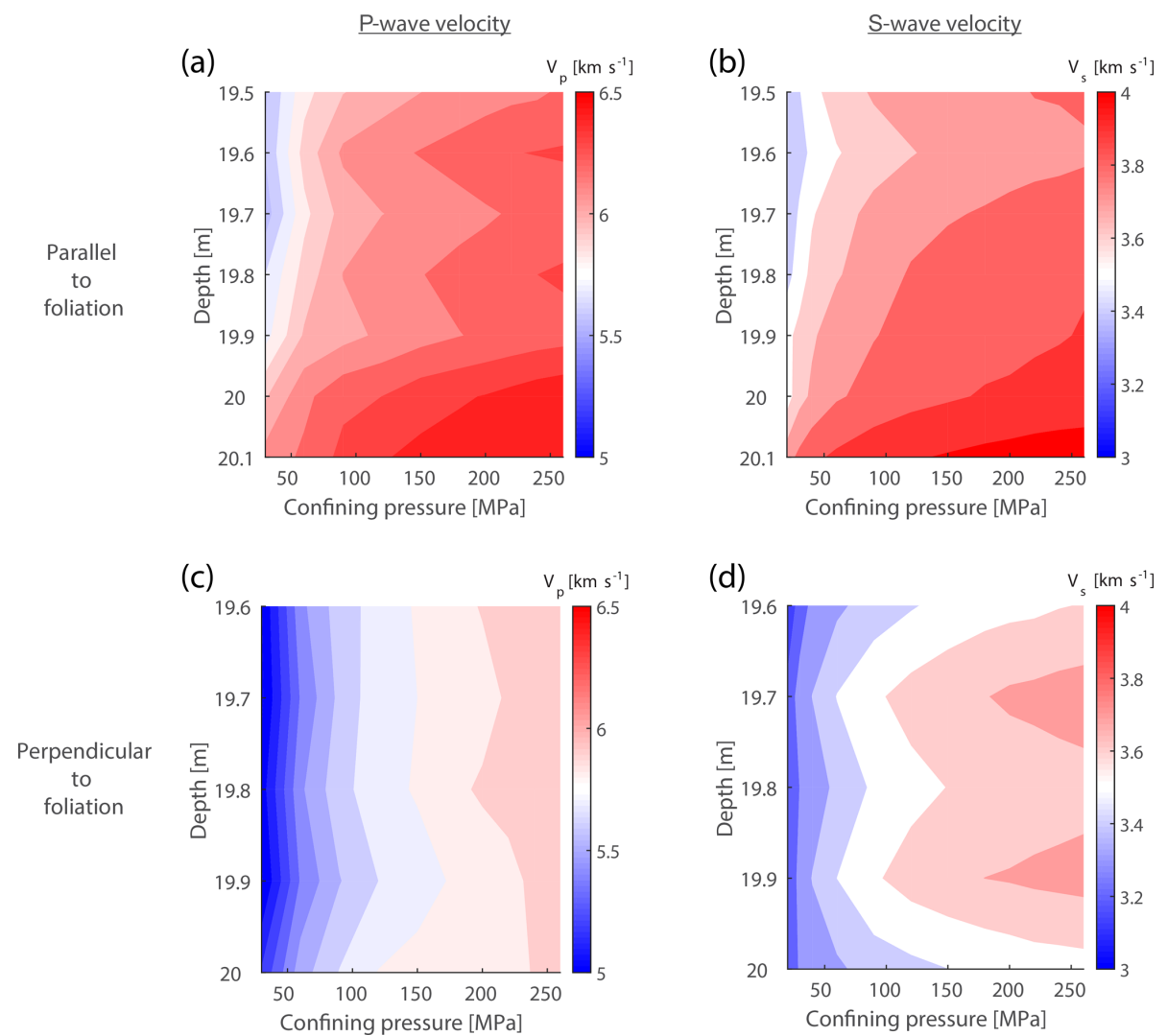

Figure 4. (a) and (b) display the results for foliation parallel velocities $\left(x_{1}\right)$ separated into $V_{\mathrm{p}}(\mathbf{a})$ and $V_{\mathrm{s}}(\mathbf{b})$. (c) and (d) display the results for foliation perpendicular velocities $\left(x_{3}\right)$ separated into $V_{\mathrm{p}}(\mathbf{c})$ and $V_{\mathrm{s}}(\mathbf{d})$. For $V_{\mathrm{p}}$ and $V_{\mathrm{s}}$ red colors indicate faster velocities and blue colors depict slower velocities (magnitude defined on the color bar).

Additionally, seismic velocities were measured up to confining pressures of $260 \mathrm{MPa}$ in order to determine the intrinsic crack-free velocities of the rocks (Fig. 4). Both $V_{\mathrm{p}}$ and $V_{\mathrm{s}}$ velocity contours show that for a given confining pressure, the velocities parallel to foliation tend to increase to maxi- mum values closest to the mylonitic core and that there is minimal sporadic variation in the perpendicular-to-foliation velocity measurements. 
Table 2. Summary of density, porosity, elastic properties and anisotropy, and permeability obtained from laboratory measurements. Laboratory velocities measured at $30 \mathrm{MPa}$ confining pressure and permeability measured at $10 \mathrm{MPa}$ effective pressure.

\begin{tabular}{|c|c|c|c|c|c|c|c|c|c|c|c|c|}
\hline Sample & Direction & $\begin{array}{r}V_{\mathrm{p}} \\
\left(\mathrm{km} \mathrm{s}^{-1}\right)\end{array}$ & $\begin{array}{l}\text { Mean } V_{\mathrm{p}} \\
\left(\mathrm{km} \mathrm{s}^{-1}\right)\end{array}$ & $\begin{array}{l}\mathrm{A} V_{\mathrm{p}} \\
(\%)\end{array}$ & $\begin{array}{r}V_{\mathrm{s}} \\
\left(\mathrm{km} \mathrm{s}^{-1}\right)\end{array}$ & $\begin{array}{l}\text { Mean } V_{\mathrm{s}} \\
\left(\mathrm{km} \mathrm{s}^{-1}\right)\end{array}$ & $\begin{array}{l}\mathrm{A} V_{\mathrm{s}} \\
(\%)\end{array}$ & $\begin{array}{r}E \\
(\mathrm{GPa})\end{array}$ & $\begin{array}{r}\mu \\
(\mathrm{GPa})\end{array}$ & $\begin{array}{r}K \\
(\mathrm{GPa})\end{array}$ & $v$ & $\begin{array}{r}k\left(\mathrm{~m}^{2}\right) \\
\times 10^{-19}\end{array}$ \\
\hline \multirow[t]{2}{*}{ SBH5 } & $x_{1}$ & 5.52 & 5.34 & 6.75 & 3.43 & 3.35 & 4.52 & 76 & 32 & 40 & 0.19 & 8.38 \\
\hline & $x_{3}$ & 5.16 & & & 3.28 & & & 68 & 29 & 33 & 0.16 & 4.14 \\
\hline \multirow[t]{2}{*}{ SBH7 } & $x_{1}$ & 5.50 & 5.30 & 7.55 & 3.42 & 3.32 & 6.30 & 76 & 32 & 40 & 0.18 & 5.95 \\
\hline & $x_{3}$ & 5.10 & & & 3.21 & & & 66 & 28 & 33 & 0.17 & 1.70 \\
\hline \multirow[t]{2}{*}{ SBH19.5 } & $x_{1}$ & 5.59 & - & - & 3.49 & - & - & 79 & 33 & 41 & 0.18 & 0.99 \\
\hline & $x_{3}$ & - & & & - & & & - & - & - & - & - \\
\hline \multirow[t]{2}{*}{ SBH19.6 } & $x_{1}$ & 5.61 & 5.30 & 11.55 & 3.54 & 3.37 & 10.01 & 81 & 35 & 41 & 0.17 & 2.11 \\
\hline & $x_{3}$ & 4.99 & & & 3.20 & & & 65 & 28 & 31 & 0.15 & 2.72 \\
\hline \multirow[t]{2}{*}{ SBH19.7 } & $x_{1}$ & 5.55 & 5.26 & 10.79 & 3.51 & 3.43 & 4.75 & 79 & 34 & 39 & 0.16 & 5.29 \\
\hline & $x_{3}$ & 4.98 & & & 3.35 & & & 67 & 31 & 27 & 0.09 & 1.36 \\
\hline \multirow[t]{2}{*}{ SBH19.8 } & $x_{1}$ & 5.70 & 5.37 & 12.14 & 3.55 & 3.43 & 7.15 & 82 & 35 & 43 & 0.18 & 5.60 \\
\hline & $x_{3}$ & 5.05 & & & 3.31 & & & 68 & 30 & 30 & 0.12 & 1.05 \\
\hline \multirow[t]{2}{*}{ SBH19.9 } & $x_{1}$ & 5.76 & 5.38 & 14.43 & 3.63 & 3.48 & 8.28 & 84 & 36 & 43 & 0.17 & 1.89 \\
\hline & $x_{3}$ & 4.99 & & & 3.34 & & & 67 & 30 & 27 & 0.09 & 1.37 \\
\hline \multirow[t]{2}{*}{ SBH20.0 } & $x_{1}$ & 5.99 & 5.60 & 13.85 & 3.68 & 3.48 & 11.55 & 90 & 38 & 49 & 0.20 & 1.55 \\
\hline & $x_{3}$ & 5.21 & & & 3.28 & & & 70 & 30 & 35 & 0.17 & 0.52 \\
\hline \multirow[t]{2}{*}{ SBH20.1 } & $x_{1}$ & 6.14 & - & - & 3.83 & - & - & 95 & 40 & 50 & 0.18 & 0.03 \\
\hline & $x_{3}$ & - & & & - & & & - & - & - & - & - \\
\hline SBH20.3 & $x_{3}$ & - & - & - & - & - & - & - & - & - & - & 0.57 \\
\hline SBH23.6 & $x_{1}$ & - & & & - & & & - & - & - & - & 0.03 \\
\hline
\end{tabular}

\subsection{Permeability measurements}

Permeability decreases (Fig. 3 and Table 2) from the host granodiorite and farthest samples in the transition zone $(0.99$ to $8.38 \times 10^{-19} \mathrm{~m}^{2}$ ) towards the samples nearest the mylonitic core $\left(0.03\right.$ to $\left.1.89 \times 10^{-19} \mathrm{~m}^{2}\right)$ along the $x_{1}$ direction (data available in Wenning et al., 2018). The permeability perpendicular to the foliation $x_{3}$ fluctuates from 0.52 to $4.14 \times 10^{-19} \mathrm{~m}^{2}$. Permeabilities of similar host Grimsel granodiorite at $5 \mathrm{MPa}$ are $10^{-18}$ to $10^{-20} \mathrm{~m}^{2}$ (David and Wassermann, 2017) and measurements on Kola granodiorite samples range from approximately $10^{-18}$ to $10^{-20} \mathrm{~m}^{2}$ at effective pressures of 10 to $50 \mathrm{MPa}$ (Morrow et al., 1994). Directional permeability of the mylonitic core was measured on two samples from separate foliated shear zones due to difficulties in sample preparation (i.e., $x_{3}$ is from $20.3 \mathrm{~m}$ depth and $x_{1}$ is from $23.6 \mathrm{~m}$ depth). The permeability is $0.03 \times 10^{-19} \mathrm{~m}^{2}$ parallel to foliation and $0.57 \times 10^{-19} \mathrm{~m}^{2}$ perpendicular to the foliation. Flow along the boundary of a quartz-filled vein that crosscuts the perpendicular sample is believed to cause the increase in permeability perpendicular to foliation in the mylonitic core.

\section{Discussion}

\subsection{Shear zone characterization}

Many studies on the transition of elastic and fluid flow properties in and around fault cores and damage zones have been concentrated on outcrop material of brittle faults (Faulkner et al., 2010). Caine et al. (1996) present models for fault core geometries, with fault cores composed of fault gouge or cataclasite. Faulkner et al. (2010) expand this model to include both single-fault core damage zones and damage zones made up of several anastamosing faults. Laboratory measurements on samples from natural fault systems have led to the development of brittle fault permeability and elastic or mechanical properties that are microfracture dependent. In such systems, damage is concentrated in the fault core, which produces fault gouge or cataclasite that can either be higher or lower in permeability than the surrounding host rock. In the host rock directly contacting the fault zone, microfracturing due to strain displacement around the fault leads to increased permeability and decreased elastic or mechanical strength (Faulkner et al., 2006). Permeability decreases and elastic or mechanical strength increases moving away from the damage zone core, as the microfracture intensity decreases away from the shear zone (e.g., Vermilye and Scholz, 1998; Wilson et al., 2003; Mitchell and Faulkner, 2009).

In ductile shear zones the alignment of anisotropic minerals in CPO or SPO due to strain accumulation has been a central focus for crustal reflectivity (e.g., Fountain et al., 1984; Jones and Nur, 1984; Kern and Wenk, 1990). Additionally, temperature and fluid content can modify measured elastic wave velocities (e.g., Griffiths et al., 2018; Nur and Simmons, 1969). Rey et al. (1994) discuss the existence of transition zones in which the strain progressively increases towards the ductile shear zone core, causing gradual changes in the physical properties around such faults. The perme- 
ability across a mylonitic ductile shear zone was estimated from relationships between porosity and pore throat radius (Géraud et al., 1995). They show that permeability is reduced in the central shear zone core but is higher in the surrounding strain gradient, which is higher than the host rock. Violay et al. (2017) performed triaxial deformation experiments in Westerly granite across the brittle-ductile transition with simultaneous measurements of porosity. The authors found that the deformation in the ductile regime is associated with compaction, while the brittle regime is primarily dilatant. For shear zones that have undergone the transition from ductile to brittle deformation, a competing process between microfracture and mineral-orientation-controlled physical properties can be envisaged.

The shear zone selected for measurements of seismic velocities and permeability in this study preserves both ductile and overprinting brittle structures. The shear zone penetrated by the borehole at GTS is characterized by foliation aligned with the mylonitic core that developed under viscous-flow deformation conditions (Wehrens et al., 2016). The foliation intensity is highest nearest the mylonitic core and decreases into the host granodiorite. The brittle fractures, which are bounded between the mylonitic cores, formed during a later brittle overprint. Figure 3 shows that the elastic and permeability transition into the mylonitic core is dissimilar to models derived from brittle fault zones (e.g., Caine et al., 1996; Faulkner et al., 2010), even though brittle deformation is evident in the damage zone. The measurements from GTS show a trend of increasing velocities and stable to decreasing permeability in the plane parallel to foliation in the transition zone. In the direction perpendicular to foliation, the velocities and permeability have minor fluctuation in the vicinity of the mylonitic core. The ductile strain gradient in the transition zone does not appear to be influenced by the later stages of brittle deformation, as indicated by the increased seismic velocities and slightly decreasing permeability parallel to foliation towards the core in the transition zone. Should there be a brittle overprint, velocities would be expected to decrease due to microfracturing; however, this is not the case (Birch, 1961; Siegesmund et al., 1991).

Instead, within the transition zone the both elastic and fluid flow properties are controlled by mineralogical changes in the rocks. Microfractures in thin section are scarce; thus, most of the $<1 \%$ porosity are intergranular micropores. It is important to note that these changes are localized within $\sim 1 \mathrm{~m}$ of the ductile mylonitic core. Since the material is bored from an underground research lab, alteration processes and weathering should be suppressed in such samples. The mineralogy of the samples shows a gradual change in composition, losing tectosilicates ( $\mathrm{Pl}, \mathrm{Fsp}$, and $\mathrm{Qz}$ ) and gaining phyllosilicates ( $\mathrm{Bt}$ and $\mathrm{Ms}$ ), through the transition zone (Fig. 3). There is an increase in foliation intensity towards the mylonitic core. The faster foliation-parallel velocities are controlled by the alignment of the platy phyllosilicate minerals (Lloyd et al., 2011a, b). Higher foliation-parallel perme- ability compared to flow perpendicular, as measured in the GTS samples, has been measured in previous studies (e.g., Faulkner and Rutter, 1998; Leclère et al., 2015; Wibberley and Shimamoto, 2003; Uehara and Shimamoto, 2004). In low grade to ductile deformation, changes in the mineralogy and foliation structure alter the connection of intergranular micropores of the platy phyllosilicate and tectosilicate minerals (e.g., Faulkner and Rutter, 1998; Leclère et al., 2015; Géraud et al., 1995). In this study the changes in mineralogy, most notably the phyllosilicate-to-tectosilicate ratio, is a driver in both the velocity and permeability anisotropy, where microcracks do not have a driving role due to their scarcity.

Outside the MCs, fractures along the borehole wall are uncommon, as indicated by optical televiewer images (Krietsch et al., 2017). Between the MCs the density of fractures is high enough to have been termed damage zone. Although some fractures penetrate the MCs, they are typically quartzfilled and generally do not connect the granodiorite on either side of the mylonitic core. In the damage zone itself, fluid flow properties and elasticity are governed by the micro and macroscopic fractures. In the damage zone the velocities are decreased and the permeability increases, indicated by logging and pump tests in the borehole (Jalali et al., 2017). Since the microfracturing does not appear to have influence outside the MCs, the displacement of these brittle features is likely small (Mitchell and Faulkner, 2012). Similar mapped faults in the region have cataclastic gouge or fault breccia (Belgrano et al., 2016), indicating that the fault at the GTS in not mature and has not accommodated much of the brittle displacement since the ductile structure is still preserved.

\subsection{Ductile-brittle transition in the fault zone}

The measurements at the GTS lead us to hypothesize how fault properties might vary not only in geometry but also in the transient evolution of the fault itself. For the transition from a ductile to brittle fault system in crystalline rock, two end-member behaviors can be envisaged: ductile and brittle. While the rock is undergoing ductile deformation and localizing along the mylonitic core shear zones, the deformation processes would be accommodated by crystal-plastic flow. The highly strained and extreme recrystallization in the ultramylonite in the mylonitic core, along with the seritization of the plagioclase in the transition zone, indicate that fluids were present and likely localized in the mylonitic core during deformation. However, once the deformation and ductile structures were frozen in, the ductile transition zone behaves in a manner where elasticity parallel to foliation increases, transitioning from the host rock to the ductile core parallel to the foliation, and permeability decreases in the core. On the other hand, in the brittle damage zone model, microfracturing induces permeability enhancement and weak elasticity nearest the fault core (e.g., Caine et al., 1996; Faulkner et al., 


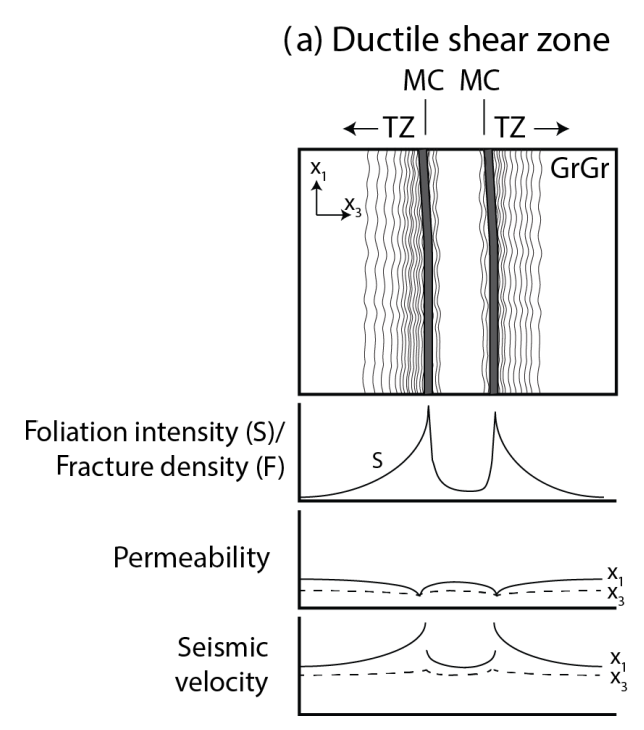

(b) Immature brittle

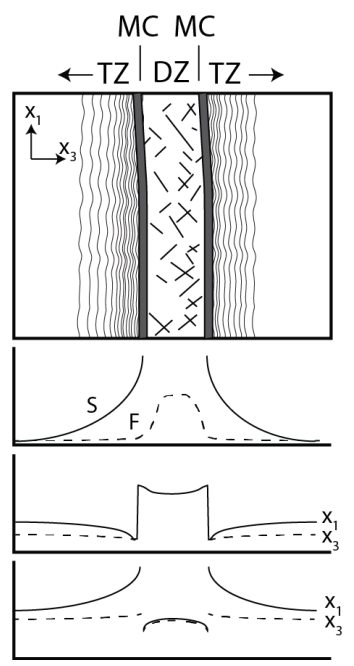

(c) Mature brittle fault

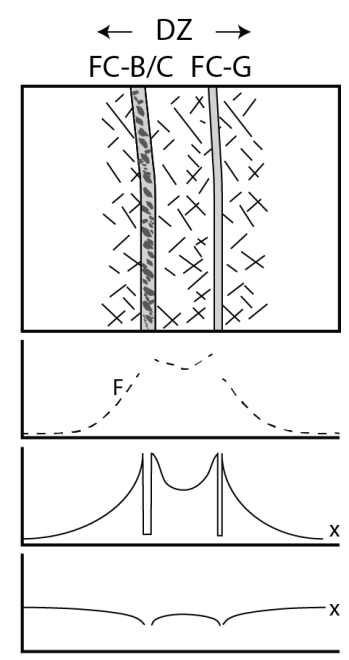

Figure 5. Conceptual model for the characteristics of faults in crystalline rock and their associated petrophysical properties during transition from ductile to brittle deformation conditions. (a) Formation of ductile shear zones with increasing foliation in the transition zone (TZ) nearest the mylonitic core (MC), (b) immature brittle fault with ductile transition zone preserved outside the MCs and the damage zone (DZ) between, and (c) mature brittle fault and DZ, where the brittle features dominate the fluid flow and elastic properties near the brittle fault cores dominated by gouge (FC-G) and breccia/cataclasite (FC-B/C) (after Faulkner et al., 2010).

2010). This case study from the GTS is a hybrid between the two end-member systems.

During the two ductile deformation phases, slip was accommodated along localized foliated shear zones that are mylonitic and ultramylonitic (Challandes et al., 2008; Rolland et al., 2009; Belgrano et al., 2016; Wehrens et al., 2016, 2017). The transition from highly foliated and extremely recrystallized mylonitic cores towards the host granodiorite represents a strain gradient, which is $\sim 0.5 \mathrm{~m}$ thick in this study (Fig. 5a). The highest foliation intensity in the granodiorite nearest the mylonitic core also creates a change in bulk mineralogy (i.e., more phyllosilicates and less tectosilicates; Fig. 3) and microstructure (i.e., more laminated; Figs. 1d and 2), which alter the petrophysical properties that, once frozen in, behave as those measured in the transition zone and mylonitic core in this study (i.e., higher seismic velocity parallel to foliation and lower permeability nearest the mylonitic core). Fluid flow channelization in ductile shear zones have been argued based on mobile elements $(\mathrm{Ca}$, $\mathrm{Mg}, \mathrm{Na}$, and $\mathrm{K})$ concentration, stabile isotopes $\left(\delta^{18} \mathrm{O}\right)$, and fluid phase observations (Etheridge et al., 1983; Marquer and Burkhard, 1992). However, in this study and the study by Géraud et al. (1995) the lowest-permeability measurements come from the mylonitic core. While the current measurements come from the frozen-in ductile microstructure, dynamic porosity changes might be occurring during deformation (e.g., Mancktelow et al., 1998), which could enhance the permeability in the mylonitic core. It is possible that the ductile shear zone would behave in such a way that the longterm permeability of the shear zone is low, creating a pressure seal. Then, during rupture, the seal releases pore pressure and causes short-term permeability enhancement in the form of microfractures and micropores around grains. This is corroborated by fractures in the feldspar grains while at conditions with quartz recrystalization.

The later stages of brittle deformation formed along the suitably oriented ductile shear zones resulting in the current fault zone geometry at the GTS shear zone (Fig. 5b). The brittle deformation is bounded by the mylonitic cores. Due to the lack of damage outside these mylonitic cores, this system is believed to be an "immature" fault, with minimal brittle slip. Outside the mylonitic cores the properties are governed by the frozen-in ductile structures. Inside the mylonitic cores the properties are heterogeneously dispersed due to the macrofractures and their associated small-scale microfractures, which reduce the seismic velocity. Recent borehole measurements from pump tests in the damage zone indicate that the transmissivity in the damage zone is $\sim 10^{-8}$ to $10^{-7} \mathrm{~m}^{2} \mathrm{~s}^{-1}$, while the host granodiorite has a transmissivity of $\sim 10^{-13}$ to $10^{-12} \mathrm{~m}^{2} \mathrm{~s}^{-1}$ (Jalali et al., 2017).

Finally, in the Grimsel region there are more "mature" brittle faults with a more pronounced damage zone and altered fault core composition (Wehrens et al., 2016; Belgrano et al., 2016). These mature brittle fault cores consist of gouges, cataclasites, and fault breccias in the middle of a fractured damage zone (Fig. 5c). The properties are expected to behave similar to the fault zone model of Faulkner et al. (2010), where there is an inverse relationship between low seismic velocity (i.e., elasticity) and high permeability around the fault core, arising due to the extensive microfracturing in the 
brittle damage zone. The fault core in such a brittle fault typically has lower permeability than the surroundings due to the clay minerals in the gouge, cataclasite, or fault breccia (e.g., Jefferies et al., 2006; Scholz, 1988; Leclère et al., 2015).

As rocks are exhumed and cooled, this system would transition from the ductile shear zone to a brittle damage zone. Thus, their mechanical properties and how fluids percolate through the entire shear zone would be highly dependent on the transient condition (depth or fault maturity) in which the fault occurs.

\subsection{Implication for geothermal energy production and waste disposal}

In crystalline rocks the elastic, mechanical, and fluid flow properties are important characteristics for the successful exploitation of natural resources. Mechanically, bulk strain can localize in the fault zone and the mechanical properties can govern earthquake rupture and fracture propagation. In terms of fluid flow, fault zones can act as both fluid conduits and barriers (e.g., Caine et al., 1996). These can be significant in terms of building or releasing pore fluid pressures closely coupled to earthquake rupture (Sibson, 1990; Leclère et al., 2015). The elastic, mechanical, and fluid flow properties of fault zones are also directly linked to geothermal projects (Rowland and Sibson, 2004), as well as the security of longterm waste storage (Barton et al., 1993; Hudson et al., 2011). With the technological advance of horizontal drilling and hydraulic fracturing the influence and interplay of mechanical and fluid flow anisotropy and heterogeneity are important when addressing stimulation in structurally complex environments (e.g., Smart et al., 2014; Busetti et al., 2014).

The case at GTS emphasizes the interplay between properties controlled by matrix mineral and fracture-controlled properties. The shear zone at GTS serves as a proxy structure expected in a geothermal reservoir. Understanding the orientation of subsurface foliation and proximity to shear zones can assist the efficiency of energy production. The interplay of matrix and fracture flow in such systems should be considered as an additional complexity. When considering the circulation of fluids, well placement in a geothermal injection/production system would need to address the geometry of subsurface heterogeneities. Present-day hydrothermal fluids in the Grimsel region flow in "pipe"-like channels (i.e., they are not uniform across the shear zone) (Belgrano et al., 2016). Mapping such structures in a crystalline basement will prove to be a challenge for the successful development of geothermal energy as a resource. Hydraulic stimulation is almost certainly required to enhance fluid flow in such crystalline systems. Mechanical anisotropy and heterogeneous pore geometries have been shown to have considerable influence on damage evolution and failure mode (e.g., Rawling et al., 2002; Baud et al., 2005; Griffiths et al., 2017). The importance of understanding the effect of mechanical discontinuities on hydraulic stimulation is shown with numer- ical models of damage propagation across mechanical layers (e.g., Smart et al., 2014). The heterogeneous and anisotropic elastic and fluid flow properties at GTS show that mechanical/elastic foliation heterogeneity must be determined, along with stress magnitude and orientation when planning the optimal borehole placement, trajectory, and stimulation design. The low permeability in the ductile mylonitic cores measured in this study suggest that there might be significant compartmentalization around such structures.

\section{Conclusions}

The shear zone at the GTS displays contrasting behavior in a single shear zone due to the fault evolution from ductile to brittle deformation. The ductile history is frozen in outside the mylonitic cores and is characterized by a transition zone of increasing foliation intensity from the host granodiorite towards the mylonitic cores. In the transition zone, the seismic velocity of the foliation-parallel samples increases towards the mylonitic core, while the velocity perpendicular to the foliation remains fairly constant. The permeability is also anisotropic and is lower in the samples nearest to and within the mylonitic core, suggesting that both permeability and seismic velocities in the transition zone are greatly influenced by the amount and texture of phyllosilicates in the rock mass. Recent brittle deformation is bounded between the foliated mylonitic cores and constitutes macroscopic fractures and associated microfractures that rarely penetrate through the mylonitic cores.

The evolution of the system from the formation of the localized shear zones in the earliest observed ductile regime (ca. $21 \mathrm{Ma}$ ) and the current brittle regime follows three steps: (1) the localization of ductile deformation, (2) shearing along the rheological discontinuity causing higher foliation intensity in the granodiorite nearest to and mylonitization of the mylonitic core, and (3) subsequent brittle deformation along the foliated mylonitic cores. We hypothesize that the properties of this shear zone suggest that brittle deformation is immature in the sense that the overprint has not effected the ductile transition zone.

Encountering such structures in geothermal reservoirs or waste disposal sites would prove to be challenging. The elastic, mechanical, and fluid flow heterogeneity caused by the mylonitic cores and their juxtaposition to a brittle damage zone would need to be considered for the optimal engineering design of any reservoir usage system.

Data availability. All data are available through https://doi.org/10.3929/ethz-b-000245921 (Wenning et al., 2018). 
Competing interests. The authors declare that they have no conflict of interest.

Acknowledgements. The seismic velocity and permeability experiments were performed in the Rock Deformation Laboratory at ETH Zurich. We thank Andrea Moscariello for allowing us to use the QEMSCAN analysis at the University of Geneva. The Swiss National Science Foundation research grant NRP-70 (Exploration and characterization of deep underground reservoirs) provided funding for this project. This study is part of the Grimsel ISC project, established by the Swiss Competence Center for Energy Research - Supply of Electricity (SCCER-SoE) with the support of the Swiss Commission for Technology and Innovation (CTI). Florian Amann, Evangelos Moulas, Valentin Gischig, Joseph Doetsch, Reza Jalali, and Hannes Krietsch are thanked for their comments and assistance during the course of this study. The authors are grateful to Telemaco Tesei and to the anonymous referee for their constructive comments that improved this paper.

Edited by: Bernhard Grasemann

Reviewed by: Telemaco Tesei and one anonymous referee

\section{References}

Allen, M., Tatham, D., Faulkner, D., Mariani, E., and Boulton, C.: Permeability and seismic velocity and their anisotropy across the Alpine Fault, New Zealand: an insight from laboratory measurements on core from the Deep Fault Drilling Project phase 1 (DFDP-1), J. Geophys. Res.-Solid Earth, 122, 6160-6179, https://doi.org/10.1002/2017JB014355, 2017.

Almqvist, B. S. and Mainprice, D.: Seismic properties and anisotropy of the continental crust: Predictions based on mineral texture and rock microstructure, Rev. Geophys., 55, 367433, https://doi.org/10.1002/2016RG000552, 2017.

Amann, F., Gischig, V., Evans, K., Doetsch, J., Jalali, R., Valley, B., Krietsch, H., Dutler, N., Villiger, L., Brixel, B., Klepikova, M., Kittilä, A., Madonna, C., Wiemer, S., Saar, M. O., Loew, S., Driesner, T., Maurer, H., and Giardini, D.: The seismo-hydromechanical behavior during deep geothermal reservoir stimulations: open questions tackled in a decameterscale in situ stimulation experiment, Solid Earth, 9, 115-137, https://doi.org/10.5194/se-9-115-2018, 2018.

Barton, C. C., Larsen, E., Page, W., and Howard, T.: Characterizing fractured rock for fluid-flow, geomechanical, and paleostress modeling: Methods and preliminary results from Yucca Mountain, Nevada, Report, Geological Survey, Denver, CO, USA, 162, 1993.

Baud, P., Louis, L., David, C., Rawling, G. C., and Wong, T.-F.: Effects of bedding and foliation on mechanical anisotropy, damage evolution and failure mode, Geological Society, London, Special Publications, 245, 223-249, 2005.

Belgrano, T. M., Herwegh, M., and Berger, A.: Inherited structural controls on fault geometry, architecture and hydrothermal activity: an example from Grimsel Pass, Switzerland, Swiss J. Geosci., 1-20, 2016.

Birch, F.: The Velocity of Compressional Waves in Rocks to 10 Kilobars, Part 1, J. Geophys. Res., 65, 1083-1102, 1960.
Birch, F.: The velocity of compressional waves in rocks to 10 kilobars: 2, J. Geophys. Res., 66, 2199-2224, 1961.

Bolognesi, F. and Bistacchi, A.: Weakness and mechanical anisotropy of phyllosilicate-rich cataclasites developed after mylonites of a low-angle normal fault (Simplon Line, Western Alps), J. Struct. Geol., 83, 1-12, 2016.

Brace, W., Walsh, J., and Frangos, W.: Permeability of granite under high pressure, J. Geophys. Res., 73, 2225-2236, 1968.

Busetti, S., Jiao, W., and Reches, Z.: Geomechanics of hydraulic fracturing microseismicity: Part 1. Shear, hybrid, and tensile events, AAPG Bulletin, 98, 2439-2457, 2014.

Caine, J. S., Evans, J. P., and Forster, C. B.: Fault zone architecture and permeability structure, Geology, 24, 1025-1028, 1996.

Challandes, N., Marquer, D., and Villa, I. M.: PTt modelling, fluid circulation, and $39 \mathrm{Ar}-40 \mathrm{Ar}$ and Rb-Sr mica ages in the Aar Massif shear zones (Swiss Alps), Swiss J. Geosci., 101, 269288, 2008.

Chester, F. and Logan, J.: Implications for mechanical properties of brittle faults from observations of the Punchbowl fault zone, California, Pure Appl. Geophys., 124, 79-106, 1986.

David, C. and Wassermann, J.: The KG2B Project: A World-Wide Benchmark of Low Permeability Measurement, Poromechanics VI: Proceedings of the Sixth Biot Conference on Poromechanics, 1153-1161, 2017.

Dicker, A. and Smits, R.: A practical approach for determining permeability from laboratory pressure-pulse decay measurements, in: International meeting on petroleum engineering, Soc. Petrol. Eng J., SPE 17578, 285-292, 1988.

Donath, F. A.: Experimental study of shear failure in anisotropic rocks, Geol. Soc. Am. Bull., 72, 985-989, 1961.

Etheridge, M., Wall, V., and Vernon, R.: The role of the fluid phase during regional metamorphism and deformation, J. Metamorph. Geol., 1, 205-226, 1983.

Faulkner, D. and Armitage, P.: The effect of tectonic environment on permeability development around faults and in the brittle crust, Earth Planet. Sci. Lett., 375, 71-77, 2013.

Faulkner, D. and Rutter, E.: The gas permeability of clay-bearing fault gouge at $20^{\circ} \mathrm{C}$, Geological Society, London, Special Publications, 147, 147-156, 1998.

Faulkner, D., Lewis, A., and Rutter, E.: On the internal structure and mechanics of large strike-slip fault zones: field observations of the Carboneras fault in southeastern Spain, Tectonophysics, 367, 235-251, 2003.

Faulkner, D., Mitchell, T., Healy, D., and Heap, M.: Slip on 'weak' faults by the rotation of regional stress in the fracture damage zone, Nature, 444, 922-925, 2006.

Faulkner, D., Jackson, C., Lunn, R., Schlische, R., Shipton, Z., Wibberley, C., and Withjack, M.: A review of recent developments concerning the structure, mechanics and fluid flow properties of fault zones, J. Struct. Geol., 32, 1557-1575, 2010.

Fountain, D. M., Hurich, C. A., and Smithson, S. B.: Seismic reflectivity of mylonite zones in the crust, Geology, 12, 195-198, 1984.

Griffiths, L., Heap, M. J., Xu, T., Chen, C.-f., and Baud, P.: The influence of pore geometry and orientation on the strength and stiffness of porous rock, J. Struct. Geol., 96, 149-160, 2017.

Griffiths, L., Lengliné, O., Heap, M., Baud, P., and Schmittbuhl, J.: Thermal cracking in Westerly Granite monitored using direct 
wave velocity, coda wave interferometry, and acoustic emissions, J. Geophys. Res.-Solid Earth, 123, 2246-2261, 2018.

Géraud, Y., Caron, J.-M., and Faure, P.: Porosity network of a ductile shear zone, J. Struct. Geol., 17, 1757-1769, 1995.

Hsieh, P., Tracy, J., Neuzil, C., Bredehoeft, J., and Silliman, S.: A transient laboratory method for determining the hydraulic properties of 'rocks' - I. Theory, in: International Journal of Rock Mechanics and Mining Sciences \& Geomechanics Abstracts, vol. 18, 245-252, Elsevier, 1981.

Hudson, J. A., Cosgrove, J. W., Kemppainen, K., and Johansson, E.: Faults in crystalline rock and the estimation of their mechanical properties at the Olkiluoto site, western Finland, Eng. Geol., 117, 246-258, 2011.

Jalali, M., Gischig, V., Doetsch, J., Krietsch, H., Amann, F., and Klepikova, M.: Mechanical, Hydraulic and Seismological Behavior of Crystalline Rock as a Response to Hydraulic Fracturing at the Grimsel Test Site, in: Proceedings of 51st US Rock Mechanics/Geomechanics Symposium, San Francisco, California, USA, ARMA 17-0962, 1-9, 2017.

Jefferies, S., Holdsworth, R., Wibberley, C., Shimamoto, T., Spiers, C., Niemeijer, A., and Lloyd, G.: The nature and importance of phyllonite development in crustal-scale fault cores: an example from the Median Tectonic Line, Japan, J. Struct. Geol., 28, 220235, 2006.

Jones, T. and Nur, A.: Seismic velocity and anisotropy in mylonites and the reflectivity of deep crystal fault zones, Geology, 10, 260263, 1982.

Jones, T. and Nur, A.: The Nature of Seismic Reflections From Deep Crustal Fault Zones, J. Geophys. Res., 89, 3153-3171, 1984.

Kern, H. and Wenk, H.-R.: Fabric-Related Velocity Anisotropy and Shear Wave Splitting in Rocks From the Santa Rosa Mylonite Zone, California, J. Geophys. Res., 95, 11213-11223, 1990.

Keusen, H., Ganguin, J., Schuler, P., Buletti, M., and Geotest: Grimsel Test Site: Geology, Report, 1-166, 1989.

Klinkenberg, L.: The permeability of porous media to liquids and gases, in: Drilling and production practice, American Petroleum Institute, 200-213, 1941.

Krietsch, H., Gischig, V., Jalali, M., Amann, F., Evans, K., Doetsch, J., and Valley, B.: Stress measurements in crystalline rock: Comparison of overcoring, hydraulic fracturing and induced seismicity results, in: Proceedings of 51st US Rock Mechanics/Geomechanics Symposium, San Francisco, California, USA, ARMA-17-0733, 1-8, 2017.

Leclère, H., Cappa, F., Faulkner, D., Fabbri, O., Armitage, P., and Blake, O.: Development and maintenance of fluid overpressures in crustal fault zones by elastic compaction and implications for earthquake swarms, J. Geophys. Res.-Solid Earth, 120, 44504473, 2015.

Lloyd, G., Butler, R., Casey, M., Tatham, D., and Mainprice, D.: Constraints on the seismic properties of the middle and lower continental crust, Geological Society, London, Special Publications, 360, 7-32, https://doi.org/10.1144/SP360.2, 2011a.

Lloyd, G., Halliday, J., Butler, R., Casey, M., Kendall, J., Wookey, J., and Mainprice, D.: From crystal to crustal: petrofabric-derived seismic modelling of regional tectonics, Geological Society, London, Special Publications, 360, 49-78, https://doi.org/10.1144/SP360.4, 2011b.
Mainprice, D.: Seismic Anisotropy of the Deep Earth from a Mineral and Rock Physics Perspective, Treatise in Geophysics - Volume 2 Mineral Physics, 437-482, 2007.

Mancktelow, N. S., Grujic, D., and Johnson, E. L.: An SEM study of porosity and grain boundary microstructure in quartz mylonites, Simplon Fault Zone, Central Alps, Contrib. Mineral. Petr., 131, 71-85, 1998.

Marquer, D. and Burkhard, M.: Fluid circulation, progressive deformation and mass-transfer processes in the upper crust: the example of basement-cover relationships in the External Crystalline Massifs, Switzerland, J. Struct. Geol., 14, 1047-1057, 1992.

Mavko, G., Mukerji, T., and Dvorkin, J.: Rock Physics Handbook: Tools for Seismic Analysis of Porous Media, 2nd Edition, Cambridge University Press, p. 524, 2009.

Mitchell, T. and Faulkner, D.: The nature and origin of off-fault damage surrounding strike-slip fault zones with a wide range of displacements: a field study from the Atacama fault system, northern Chile, J. Struct. Geol., 31, 802-816, 2009.

Mitchell, T. and Faulkner, D.: Towards quantifying the matrix permeability of fault damage zones in low porosity rocks, Earth Planet. Sci. Lett., 339, 24-31, 2012.

Morrow, C., Lockner, D., Hickman, S., Rusanov, M., and Röckel, T.: Effects of lithology and depth on the permeability of core samples from the Kola and KTB drill holes, J. Geophys., 99, 7263-7274, 1994.

NIST: http://webbook.nist.gov/chemistry/fluid/ (last access: 30 June 2017), National Institute of Standards and Technology, 2017.

Nur, A. and Simmons, G.: The effect of saturation on velocity in low porosity rocks, Earth Planet. Sc. Lett., 7, 183-193, 1969.

Pini, R., Ottiger, S., Burlini, L., Storti, G., and Mazzotti, M.: Role of adsorption and swelling on the dynamics of gas injection in coal, J. Geophys. Res.-Solid Earth, 114, 1-14, https://doi.org/10.1029/2008JB005961, 2009.

Rawling, G. C., Baud, P., and Wong, T.: Dilatancy, brittle strength, and anisotropy of foliated rocks: Experimental deformation and micromechanical modeling, J. Geophys. Res.-Solid Earth, 107, 1-14, https://doi.org/10.1029/2001JB000472, 2002.

Rey, P. F., Fountain, D. M., and Clement, W. P.: P wave velocity across a noncoaxial ductile shear zone and its associated strain gradient: Consequences for upper crustal reflectivity, J. Geophys. Res., 99, 4533-4548, 1994.

Rolland, Y., Cox, S. F., and Corsini, M.: Constraining deformation stages in brittle-ductile shear zones from combined field mapping and $40 \mathrm{Ar} / 39 \mathrm{Ar}$ dating: the structural evolution of the Grimsel Pass area (Aar Massif, Swiss Alps), J. Struct. Geol., 31, 13771394, 2009.

Rowland, J. and Sibson, R.: Structural controls on hydrothermal flow in a segmented rift system, Taupo Volcanic Zone, New Zealand, Geofluids, 4, 259-283, 2004.

Schaltegger, U. and Corfu, F.: The age and source of late Hercynian magmatism in the central Alps: evidence from precise $\mathrm{U}-\mathrm{Pb}$ ages and initial Hf isotopes, Contrib. Mineral. Petr., 111, 329-344, 1992.

Scholz, C.: The brittle-plastic transition and the depth of seismic faulting, Geol. Rundsch., 77, 319-328, 1988.

Sibson, R. H.: Continental fault structure and the shallow earthquake source, J. Geol. Soc., 140, 741-767, 1983. 
Sibson, R. H.: Rupture nucleation on unfavorably oriented faults, B. Seismol. Soc. Am., 80, 1580-1604, 1990.

Sibson, R. H.: Crustal stress, faulting and fluid flow, Geological Society, London, Special Publications, 78, 69-84, 1994.

Siegesmund, S., Kern, H., and Vollbrecht, A.: The effect of oriented microcracks on seismic velocities in an ultramylonite, Tectonophysics, 186, 241-251, 1991.

Smart, K. J., Ofoegbu, G. I., Morris, A. P., McGinnis, R. N., and Ferrill, D. A.: Geomechanical modeling of hydraulic fracturing: Why mechanical stratigraphy, stress state, and pre-existing structure matter, AAPG Bulletin, 98, 2237-2261, 2014.

Sone, H. and Zoback, M. D.: Mechanical properties of shalegas reservoir rocks - Part 1: Static and dynamic elastic properties and anisotropy, Geophysics, 78, D378-D389, https://doi.org/10.1190/Geo2013-0050.1, 2013.

Steck, A.: Die alpidischen Strukturen in den Zentralen Aaregraniten des westlichen Aarmassivs, Eclogae Geol. Helv., 61, 19-48, 1968.

Uehara, S.-I. and Shimamoto, T.: Gas permeability evolution of cataclasite and fault gouge in triaxial compression and implications for changes in fault-zone permeability structure through the earthquake cycle, Tectonophysics, 378, 183-195, 2004.

Vermilye, J. M. and Scholz, C. H.: A microstructural view of fault growth, J. Geophys. Res., 103, 12223-12237, 1998.

Vidal, J. and Genter, A.: Overview of naturally permeable fractured reservoirs in the central and southern Upper Rhine Graben: Insights from geothermal wells, Geothermics, 74, 57-73, 2018.

Violay, M., Heap, M., Acosta, M., and Madonna, C.: Porosity evolution at the brittle-ductile transition in the continental crust: Implications for deep hydro-geothermal circulation, Sci. Rep., 7, 1-10, https://doi.org/10.1038/s41598-017-08108-5, 2017.
Watanabe, N., Numakura, T., Sakaguchi, K., Saishu, H., Okamoto, A., Ingebritsen, S. E., and Tsuchiya, N.: Potentially exploitable supercritical geothermal resources in the ductile crust, Nat. Geosci., 10, 140-144, https://doi.org/10.1038/ngeo2879, 2017.

Wehrens, P., Berger, A., Peters, M., Spillmann, T., and Herwegh, M.: Deformation at the frictional-viscous transition: Evidence for cycles of fluid-assisted embrittlement and ductile deformation in the granitoid crust, Tectonophysics, 693, 66-84, 2016.

Wehrens, P., Baumberger, R., Berger, A., and Herwegh, M.: How is strain localized in a meta-granitoid, mid-crustal basement section? Spatial distribution of deformation in the central Aar massif (Switzerland), J. Struct. Geol., 94, 47-67, 2017.

Wenning, Q. C., Madonna, C., de Haller, A., and Burg, J.P.: Dataset for "Permeability and seismic velocity anisotropy across a ductile-brittle fault zone in crystalline rock", https://doi.org/10.3929/ethz-b-000245921, 2018.

Wibberley, C. A. and Shimamoto, T.: Internal structure and permeability of major strike-slip fault zones: the Median Tectonic Line in Mie Prefecture, Southwest Japan, J. Struct. Geol., 25, 59-78, 2003.

Wilson, J., Chester, J., and Chester, F.: Microfracture analysis of fault growth and wear processes, Punchbowl Fault, San Andreas system, California, J. Struct. Geol., 25, 1855-1873, 2003.

Zappone, A., Fernandez, M., Garcia-Duenas, V., and Burlini, L.: Laboratory measurements of seismic P-wave velocities on rocks from the Betic chain (southern Iberian Peninsula), Tectonophysics, 317, 259-272, https://doi.org/10.1016/S00401951(99)00319-4, 2000. 